\title{
In Vitro plant regeneration from leaf explants of Tagetes erecta $\mathbf{L}$.
}

\author{
J. L. Munshi*, R. Baksha, M. Z. Rahaman, N. N. Huque, E. A. Zinat and N. Momtaz \\ Biological Research Division, Bangladesh Council of Scientific \& Industrial Research (BCSIR), Dhaka-1205, Bangladesh
}

Received: 19 October 2020

Revised: 30 December 2020

Accepted: 31 March 2021

DOI: https://doi.org/10.3329/bjsir.v56i1.54313

\begin{abstract}
Regeneration of multiple shoots via callus induction and organogenesis was obtained from young leaf explants of the field grown marigold (Tagetes erecta L.). Callus induction and shoot regeneration at various frequencies were observed using different concentrations and combinations of growth regulators. Highest percentage ( $90 \%$ ) of callus formation was observed within two weeks on MS medium supplemented with $5.0 \mathrm{mg} / \mathrm{l} \mathrm{BAP}$ with $2.5 \mathrm{mg} / \mathrm{l} \mathrm{NAA}$. The maximum percentage ( $80 \%$ ) of shoot bud formation ( $10 \pm 0.5 /$ callus) was obtained from MS medium containing $1.0 \mathrm{mg} / 1$ BAP with $0.5 \mathrm{mg} / \mathrm{l}$ kinetin. The regenerated shoots developed highest percentages $(90 \%)$ of roots on half strength MS medium supplemented with $1.0 \mathrm{mg} / \mathrm{l}$ IBA. The plantlets when transferred into potsoil $80 \%$ survived. Regenerated plants were morphologically uniform with normal leaf shape and growth pattern.
\end{abstract}

Keywords: In vitro; Tagetes erecta L.; Callus induction; Regeneration; Acclimatization

\section{Introduction}

Marigold (Tagetes erecta L.) is an annual herbaceous medicinal plant of the botanical Family: Compositae and is presently grown in almost all tropical countries including Bangladesh. It is often cultivated in homestead gardens and as pot plants. Besides attractive flower colors, both leaves and flowers are equally important medicinally. The plant is effective against in emmenagogue, piles, rheumatism, colds, bronchitis, kidney troubles and muscular pains (Ghani, 1998). It has been also noticed that Tagetes are highly effective in keeping the population of nematode under control (Khan et al., 1971; Lehman, 1979; Siddiqui and Alam, 1988). The nematocidal effect is attributed to the presence of thiophenes (Chan et al., 1975), which are naturally occurring biocides (Croes et al., 1989, Hulst et al., 1989). Because of its aesthetic, medicinal and commercial values the demand of Tagetes has been steadily increasing.

The plant is generally propagated by seeds and cuttings. Seed germination is unreliable due to its poor rate. Sometimes Tagetes production declines due to incidence of viral and other diseases which may cause a great extent of commercial losses (Sastry et al., 2019). Tissue culture techniques provide a fast and dependable method for production of a large number of disease free, uniform plantlets in a shorter period of time. Several authors have reported about the micro propagation of Tagetes spp. but the reproducibility of the results was not satisfactory (Kothari and Chandra, 1984, 1986; Bespalhok and Hattori, 1998; Misra and Datta, 2001). However, further improvement of the protocol is essential because it is one of the major pre-requisites for genetic manipulation and to improve the quantity and quality of planting material to approach for safe, long-term maintenance of valuable germ plasm, developed through breeding programmes (Vanegas et al., 2002). Thus, the present study was undertaken to develop an improved and easily reproducible protocol for multiplication of $T$. erecta through organogenesis.

\section{Materials and methods}

The experiment was conducted at Biological Research Division, Bangladesh Council of Scientific and Industrial Research (BCSIR), Dhaka, Bangladesh. The apical shoot tips with leaf primordia $(2-4 \mathrm{~mm})$ were collected from 
2-3 month old field grown $T$. erecta and used as primary explants. First explants were washed under running tap water for $10-15 \mathrm{~min}$ and then surface sterilized with $0.1 \% \mathrm{HgCl}_{2}$ for $10 \mathrm{~min}$ followed by five to six rinses with sterilized distilled water further. For callus induction the leaf segment of 2-4 $\mathrm{mm}$ length were excised and were inoculated in $150 \times 25 \mathrm{~mm}$ culture tubes containing MS (Murashige and Skoog, 1962) supplemented with various combinations and concentrations of auxins and cytokinins and with $0.6 \%$ agar $\mathrm{pH}$ 5.7. Six callus induction media (CIM) were used. CIM1 and CIM2 media contained BAP 1.0 and $2.0 \mathrm{mg} / \mathrm{l}$, respectively, CIM3 medium contained BAP $2.5 \mathrm{mg} / \mathrm{l}$ with NAA $0.5 \mathrm{mg} / \mathrm{l}$, CIM4 medium contained BAP $5.0 \mathrm{mg} / \mathrm{l}$ with NAA $2.5 \mathrm{mg} / 1$. CIM5 medium contained BAP $10 \mathrm{mg} / 1$ with NAA $5.0 \mathrm{mg} / \mathrm{l}$ and CIM6 medium contained no growth regulators.

In the present protocol, four regeneration media (RM1, RM2, RM3 and RM4) supplemented with kinetin $(0.5 \mathrm{mg} / \mathrm{l})$ and different combinations of BAP $(0.5,1.0,3.0$ and $5.0 \mathrm{mg} / \mathrm{l})$ were used as treatment for plant regeneration. Twenty five shoots were used per treatment with three replications. For root induction, $>1.0 \mathrm{~cm}$ long micro shoots were inoculated in the rooting medium containing half strength MS media with various concentrations of auxin and sucrose for root induction. Inoculated cultures were incubated at $25 \pm 2^{\circ} \mathrm{C}$ under fluorescent tube light with $16 \mathrm{~h}$ photoperiod and data were recorded after 3 weeks of culture.

For hardening, the culture tubes containing rooted shoots were kept at room temperature under light for $14 \mathrm{~d}$. Then the rooted shoots were removed from culture tubes, washed thoroughly to free agar from roots and finally transplanted into small pots containing soil. Plantlets were well covered with a piece of polythene sheet for three weeks to ensure high humidity while watering was continued regularly.

\section{Results and discussion}

Calli were developed at the cut surfaces of the leaf explants within 8-10 d of inoculation and subsequently covered the entire surfaces within 15-18 d in the callus induction media. Although, callus induction was observed in all media but there was a wide range of variation in percentages of callus formation as well as color and texture of the callus (Table I). Callus induction was not found in MS medium without growth regulators even after four weeks of culture. The most rapid and prolific callus response was obtained from a combination of $5.0 \mathrm{mg} / \mathrm{l}$ BAP with $2.5 \mathrm{mg} / \mathrm{l} \mathrm{NAA}$. The highest percentages $(90 \%)$ of callus formation were observed on this medium compared to other media $10.0 \mathrm{mg} / \mathrm{l} \mathrm{BAP}$ with $5.0 \mathrm{mg} / 1 \mathrm{NAA}(49 \%), 2.5 \mathrm{mg} / 1 \mathrm{BAP}$ with $0.5 \mathrm{mg} / 1 \mathrm{NAA}$ (58\%), $2.5 \mathrm{mg} / \mathrm{l} \mathrm{BAP} \mathrm{(45 \% )} \mathrm{and} 1.0 \mathrm{mg} / \mathrm{l} \mathrm{BAP} \mathrm{(25 \% ).} \mathrm{Calli}$ were found hard and compact, which were initiated on media
Table I . Effects of auxins and cytokinin on callus formation from leaf explants of Tagetes erecta

\begin{tabular}{ccccc}
\hline $\begin{array}{c}\text { Growth } \\
\text { regulator } \\
\text { cons. (mg/l) }\end{array}$ & $\begin{array}{c}\text { Days to } \\
\text { initiation }\end{array}$ & Color & Texture & $\begin{array}{c}\% \text { of callus } \\
\text { formation }\end{array}$ \\
\hline BAP+NAA & & & & \\
\hline 1.0 & 20 & LG & C & 25 \\
2.5 & 15 & LG & C & 45 \\
$2.5+0.5$ & 12 & LG & C & 58 \\
$5.0+2.5$ & 10 & WG & C & 90 \\
$10+5.0$ & 15 & HG & H,C & 49 \\
0.0 & - & - & - & - \\
\hline
\end{tabular}

$\mathrm{WG}=$ White green, $\mathrm{LG}=$ Light green, $\mathrm{HG}=$ Heavily green, $\mathrm{C}=$ Compact, $\mathrm{H}=$ Hard Data were taken from 45 replications per treatment 28 days after inoculation.

supplemented with higher concentrations of hormonal combinations. The results of the present experiment agree with the findings of Kothari and Chandra (1986). They found that a combination of BAP, NAA and $\mathrm{GA}_{3}$ (gibberellic acid) was suitable for high frequency callus production in Tagetes.

However, Ketel et al. (1985) reported that certain marigold species i.e T. erecta and T. patula are difficult to culture in vitro due to browning of explants that led to poor callus growth or death of explants. Our results showed that, young leaf of $T$. erecta provides an excellent material to obtain most rapid and prolific callus formation. This might be due to genotypic variation of explants reinforced by the cultural and environmental conditions.

Table II shows the capacity of shoot bud differentiation and shoot proliferation from leaf derived calli of T.erecta depended on hormonal variation. For shoot formation green nodular compact calli were cultured on MS medium containing different concentration of BAP with Kinetin for shoot formation. The highest percentages of shoot formation were observed in MS medium containing $1.0 \mathrm{mg} / 1 \mathrm{BAP}$ with $0.5 \mathrm{mg} / \mathrm{l} \mathrm{kinetin}$. The explants showed shoot initiation after 10-15 days (Fig.1a). In this medium $80 \%$ of cultures were found to regenerate shoots and the number of regenerated shoots per explants was $10 \pm 0.5$. In MS medium 
Table II. Shoot proliferation from leaf explants derived calluses of Tagetes erecta*

\begin{tabular}{|c|c|c|c|c|}
\hline $\begin{array}{l}\text { Growth } \\
\text { regulator } \\
\text { conc. } \\
(\mathrm{mg} / \mathrm{l})\end{array}$ & $\begin{array}{c}\text { Days to shoot } \\
\text { initiation }\end{array}$ & No. of shoots & $\begin{array}{c}\text { Length of } \\
\text { shoots }(\mathrm{cm})^{* *}\end{array}$ & $\begin{array}{l}\% \text { of shoot } \\
\text { formation }\end{array}$ \\
\hline \multicolumn{5}{|l|}{$\begin{array}{l}\text { BAP+ } \\
\text { Kinetin }\end{array}$} \\
\hline $0.5+0.5$ & $15-20$ & $3.0 \pm 0.45$ & $1.6 \pm 0.25$ & 62 \\
\hline $1.0+0.5$ & $10-15$ & $10.0 \pm 0.50$ & $3.0 \pm 0.15$ & 80 \\
\hline $3.0+0.5$ & $7-10$ & $5.0 \pm 0.10$ & $2.8 \pm 0.10$ & 50 \\
\hline $5.0+0.5$ & $15-18$ & $4.50 \pm 0.30$ & $1.9 \pm 0.40$ & 45 \\
\hline
\end{tabular}

* Data were taken from 45 replications per treatment 28 days after inoculation.

* Mean \pm standard error.

Table III. Rhizogenesis from microshoots of Tagetes erecta on half strength of MS medium supplemented with different concentrations of IBA and IAA*

\begin{tabular}{ccccc}
\hline $\begin{array}{c}\text { Growth } \\
\text { regulator } \\
\text { conc. } \\
(\mathrm{mg} / \mathrm{l})\end{array}$ & $\begin{array}{c}\text { Days to shoot } \\
\text { initiation }\end{array}$ & No. of roots & $\begin{array}{c}\text { Length of } \\
\text { roots }(\mathrm{cm})^{* *}\end{array}$ & $\begin{array}{c}\text { \% of root } \\
\text { formation }\end{array}$ \\
\hline IBA & 10 & $2.0 \pm 0.30$ & $1.5 \pm 0.15$ & 50 \\
\hline 0.5 & $5-7$ & $8.0 \pm 0.50$ & $3.0 \pm 0.30$ & 90 \\
1.0 & 10 & $2.5 \pm 0.45$ & $2.5 \pm 0.10$ & 70 \\
1.5 & $10-12$ & $2.2 \pm 0.35$ & $2.0 \pm 0.05$ & 65 \\
2.0 & 14 & $1.0 \pm 0.40$ & $1.0 \pm 0.25$ & 35 \\
\hline IAA & 10 & $4.0 \pm 0.25$ & $2.0 \pm 0.15$ & 60 \\
\hline 0.5 & 12 & $1.5 \pm 0.50$ & $1.8 \pm 0.05$ & 45 \\
1.0 & $12-15$ & $1.0 \pm 0.35$ & $1.5 \pm 0.25$ & 40 \\
1.5 & 14 & & & \\
\hline
\end{tabular}

* Data were taken from 45 replications per treatment 28 days after inoculation.

** Mean \pm standard error. 
supplemented with BAP $(0.5 \mathrm{mg} / \mathrm{l})$ with kinetin $(0.5 \mathrm{mg} / \mathrm{l})$, 2-3 shoot developed within 15-20 days (Fig. 1b). Media containing a high level of BAP $(3.0-5.0 \mathrm{mg} / \mathrm{l})$ with Kinetin $(0.5 \mathrm{mg} / \mathrm{l})$ yielded a few of shoots and decreased with further more increase in BAP concentrations. Kothari and Chandra (1984, 1986) and Vanegas et al. (2002) reported that development of adventitious shoot bud was observed on a medium with different concentrations of BAP with IAA. On the contrast, in the present study, there was a good shoot bud initiation and proliferation response only in the presence of cytokinins (BAP with kinetin). The cytokinins are generally added to a culture media to stimulate cell division, to induce shoot formation and axillary shoot proliferation. Our results showed that, an absolute cytokinin may be required for Tagetes organogenesis from leaf explants. The potential of calli to differentiate was ascribed to a phytohormone effect mediated by differential gene activity (Breteler and Ketel 1993).

For adventitious root formation elongated healthy shoots (3-4 $\mathrm{cm}$ in length) were excised and transferred to the half strength MS media supplemented with different concentrations $(0.5-2.0 \mathrm{mg} / \mathrm{l})$ of IBA and IAA. In most cases, root initiation started with in 7-10 days of culture
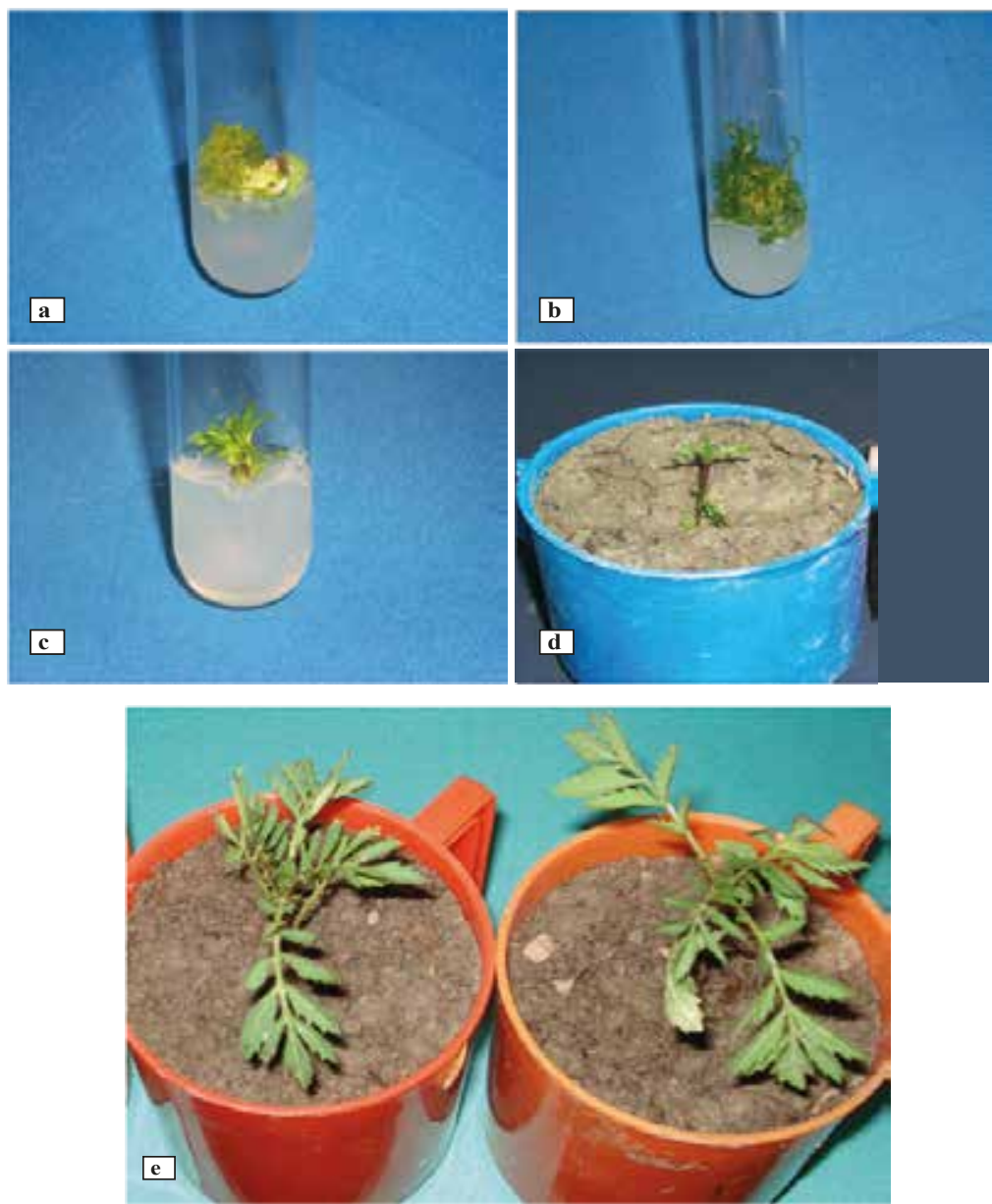

Fig. 1 (a-e). Different stages of plant regeneration from leaf explants in Tagetes erecta a. Callus induction in MS supplemented with $5.0 \mathrm{mg} / \mathrm{l} \mathrm{BAP}$ and $2.5 \mathrm{mg} / \mathrm{l} \mathrm{NAA}$

b. Regeneration of multiple shoots in MS supplemented with $1.0 \mathrm{mg} / \mathrm{l} \mathrm{BAP}$ and $0.5 \mathrm{mg} / \mathrm{l} \mathrm{kinetin}$

c. Root induction in half strength MS with $1.0 \mathrm{mg} / \mathrm{l}$ of IBA

d. and e. Hardened plantlets transferred to soil 
(Fig.1c). It may be mentioned that, root induction was not observed in MS medium which was free from any hormonal supplement. Best response observed when 1.0 $\mathrm{mg} / \mathrm{l}$ of IBA was used (Table III). In this medium, 90\% shoots rooted within four weeks of culture and each microcutting produced 6-8 roots. Similar effects of IBA were reported in Ocimum americanum L. syn, O. canum Sims and O.sanctum L. (Pattnaik and Chand, 1996). Root developed in medium containing lower concentration IBA or IAA $(0.5 \mathrm{mg} / \mathrm{l})$ was poor in quality. On the other hand, medium containing higher concentrations of IBA or IAA (2.0 mg/l) always formed root accompanied with callusing. The proper stage of root development is another criterion for selecting plantlets to be transferred into the soil. In vitro regenerated plantlets were transferred to small pots for future establishment (Fig.1d). After 10-15 days when the plants were fully acclimated to outdoor conditions, they were then transplanted in the earthen pots (Fig. 1e).

The present report showed that MS medium containing $1.0 \mathrm{mg} / 1 \mathrm{BAP}$ with $0.5 \mathrm{mg} / 1$ kinetin proved more effective for multiple shoot formation from the leaf explants derived calli. The technique described here appears to be readily adaptable for large scale propagation of this important medicinal and ornamental plant to earn foreign exchange and also to meet the local demand.

\section{Conclusion}

Multiple shoots were obtained from young leaf induced callus of $T$. erecta. Our study demonstrated that MS medium with BAP and NAA combination induced highest percentage of callus, whereas BAP with Kinetin produced maximum shoots from callus. Maximum roots were produced in half strength MS medium with IBA. When transferred to soil, $80 \%$ plantlets survived. The technique described here is a promising method of micro propagation of T.erecta to a larger scale. In order to make it more effective further experiments should be done at the stage of acclimatization using different types of soil media combinations.

\section{Acknowledgement}

The authors would like to thank Director, BCSIR Laboratories Dhaka for providing valuable technical support to this project. This research was supported by BCSIR R\&D project (2012-13) entitled 'In vitro and conventional propagation of some medicinal plants'.

\section{References}

Bespalhok JCF and Hattori K (1998), Friable embryogenic callus and somatic embryo formation from cotyledon explants of African marigold (Tagetes erecta L), Plant Cell Reports. 17(11): 870-875. DOI: org/10.1007/ s002990050500

Breteler H and Ketel DH (1993), Tagetes spp. (Marigold): In vitro culture and the production of thiophenes: In: Biotechnology in agriculture and forestry, Medicinal and aromatic plants iv., Ed. Bajaj YPS, Springer-Verlag, Berlin, Heidelberg, Vol. 21: 387-412.

Chan GFQ, Towers GHN and Mitchell JC (1975), Ultra-violate mediated antibiotic activity of thiophene compounds of Tagetes, Phytochem. 14: 2295-2296. DOI: org/10.1016/S0031-9422(00)91121-X

Croes AF, Aarts M, Bosveld M, Breteler H and Wullems GJ (1989), Control of thiophene accumulation in calli of two Tagetes species, Physiol Plant. 76: 205-210. DOI: org/10.1111/j.1399-3054.1989.tb05633.x

Ghani A (1998), Medicinal plants of Bangladesh: Chemical constituents and uses, Asiatic Society of Bangladesh, pp 301-302.

Hulst AC, Meyer MMT, Breteler H and Tramper J (1989), Effect of aggregate size in Tagetespatula on thiophene production and cell growth, Appl. Microbiol and Biotech. 30: 18-25.

Ketel DH, Breteler H and De Groot B (1985), Effect of explant origin on growth and differentiation of calli from Tagetes species, J. Plant Physiol. 118: 327-333. DOI: org/10.1016/S0176-1617(85)80191-7

Khan AM, Saxena SK and Siddiqi ZA (1971), Efficacy of Tagetes erecta in reducing root infesting nematodes of tomato and okra, Indian Phytopathology 24: 166-169.

Kothari SL and Chandra N (1986), Plant regeneration in callus and suspension culture of Tagetes erecta L (African marigold), Journal of Plant Physiology. 122(3): 235-241. DOI: org/10.1016/ S0176-1617 (86)80122-5 
Kothari SL and Chandra N (1984), In vitro propagation of African marigold, Hort Science 19(5): 703-705.

Lehman PS (1979), Factors influencing nematode control with marigolds, Nematology Circular No, 50, Florida Department of Agriculture and Consumer Services, Division of Plant Industry, Gaines Ville, Fl.

Misra P and Datta SK (2001), Direct differentiation of shoot buds in leaf segments of white marigold (Tagetes erecta L). In vitro Cellular and Development Biology-Plant, Vol 37(4): pp 466-470.

Murashige T and Skoog F (1962), A revised medium for rapid growth and bioassays with tobacco tissue cultures, Physiol. Plant. 15: 443-477. DOI: org/10.1111/j.1399-3054.1962.tb08052.x
Pattnaik SK and Chand PK (1996), In vitro propagation of the medicinal herbs, Plant Cell Reports 15: 846-850.

Sastry KS, Mandal B, Hammond J, Scott SW and Briddon RW (2019), Tagetes spp. (Marigold) In: Encyclopedia of Plant Viruses and Viroids, Springer, New Delhi. DOI: org/10.1007/978-81-322-3912-3_926.

Siddiqui MA and Alam MM (1988), Toxicity of different plant parts of Tageteslucida to plant parasitic nematodes, Indian Journal of Nematology 18: 181-185.

Vanegas PE, Hernandez AC, Valverde ME and Lopez OP (2002), Plant regeneration via organogenesis in marigold, Plant Cell, Tissue and Organ Culture. 69(3): 279-283. 